\title{
The Patterns and Mechanisms of Land Price Divergence in Multiple Industries from the Perspective of Element Flows: The Case of the Yangtze River Delta, China
}

\author{
Shuyun $\mathrm{Hu}^{1}{ }^{1}$, Dazhuan Ge ${ }^{1, *} \mathbb{0}$, Guojian $\mathrm{Hu}^{1}{ }^{1}$, Jingwen Sun ${ }^{1}$, Yingyi $\mathrm{Ma}^{2}$, Mengqiu Lu ${ }^{3}$ and Yuqi $\mathrm{Lu}^{1}$ \\ 1 School of Geography, Nanjing Normal University, Nanjing 210023, China; 191302032@njnu.edu.cn (S.H.); \\ 191301007@njnu.edu.cn (G.H.); 201301011@njnu.edu.cn (J.S.); luyuqi@njnu.edu.cn (Y.L.) \\ 2 School of Architectural Engineering, Jinling Institute of Technology, Nanjing 211169, China; \\ mayingyi@jit.edu.cn \\ 3 School of International Economics and Trade, Nanjing University of Finance and Economics, \\ Nanjing 210023, China; mqlu3201@nufe.edu.cn \\ * Correspondence: gedz@njnu.edu.cn; Tel.: +86-25-8589-1347
}

check for updates

Citation: Hu, S.; Ge, D.; Hu, G.; Sun, J.; Ma, Y.; Lu, M.; Lu, Y. The Patterns and Mechanisms of Land Price Divergence in Multiple Industries from the Perspective of Element Flows: The Case of the Yangtze River Delta, China. Land 2022, 11, 188. https://doi.org/10.3390/ land 11020188

Academic Editors: Fabrizio Battisti and Dagmar Haase

Received: 4 December 2021

Accepted: 20 January 2022

Published: 25 January 2022

Publisher's Note: MDPI stays neutral with regard to jurisdictional claims in published maps and institutional affiliations.

Copyright: (C) 2022 by the authors. Licensee MDPI, Basel, Switzerland. This article is an open access article distributed under the terms and conditions of the Creative Commons Attribution (CC BY) license (https:// creativecommons.org/licenses/by/ $4.0 /)$.

\begin{abstract}
An in-depth exploration of the inner mechanisms of the spatio-temporal evolution of land prices in multiple industries (residential, commercial service and industrial) is of great significance for improving the overall economic development efficiency and resource allocation capacity of the region. Based on urban land price transaction data provided by the China Land Market Network, 307 countylevel units in the Yangtze River Delta were used as the study area and spatial auto-correlation and spatio-temporal hotspot analysis were used to explore the spatial variation and temporal changes of land prices in multiple industries in the Yangtze River Delta from 2008 to 2018. The three-dimensional driving theory of land "demand + supply + market" was used as the basis to construct the index system of influential factors and the Spatial Durbin Model was used to explore the mechanism of the spatio-temporal variation of land prices in multiple industries. The results show that the land prices of multiple industries in the Yangtze River Delta are generally high in the east and low in the west and high in the south and low in the north, which is spatially consistent with the level of regional economic development. Due to the disparity in economic development between the regions, factors such as population, capital, technology and information are redistributed and fed into each other's cycles between cities. The resulting spatial differences in land market supply and demand are intrinsic to the spatial differentiation of urban land prices. It is further proposed that land prices are a monetized expression of the abundance of resources in a city and that land prices are determined by the combined ability of regional resource factors to be allocated. Thus, land price differentiation reflects differences in the level of comprehensive regional development. Finally, the dynamic interaction of various factors on land values is used to promote the division of urban functions and regional economic development, which is an effective way to promote high-quality integrated regional development.
\end{abstract}

Keywords: spatial structure of land prices; land price of multiple industries; spatial and temporal differentiation; influencing factors; Yangtze River Delta; counties

\section{Introduction}

Land has multiple attributes and can be a resource, an asset or a form of capital. Given the continuous promotion of urbanization in China, land, which is one of the basic factors in industrial production, residential life and commercial activities in cities and towns [1], carries different functions in the operation of urban systems. Land prices, as the most sensitive indicator of land supplies and demand and a value-judgment standard for land market operation, reflect the current situation of urban land use and the trend of changes 
in land use types [2]. Thus, land prices not only provide an important basis for the industrial layout and functional positioning of cities in urban clusters of different development types, but they also relate to the implementation of China's regional planning and development strategies [3]. It plays a pivotal role in promoting socio-economic development and transformation. In recent years, the rapid rise in land prices in Chinese cities, especially mega-cities, has had a significant impact on the purchase of housing by residents and the location of enterprises and high land prices have become one of the typical manifestations of agglomeration dis-economies [4]. As an important part of urban capital investment, high or low land costs can "crowd out" or "drain" investment in industrial technology and human capital from the urban economy, limiting its growth and reducing the efficiency and quality of economic development [5]. Due to the complex formation and influencing factors of land prices, it is difficult to regulate land market prices solely by means of supply in China's current non-fully competitive land market system, resource characteristics and macroeconomic context.

Current research on land prices has generally revolved around an analysis of the spatial heterogeneity $[6,7]$ or evolutionary patterns $[8,9]$ of prices of single land use types, with the aim of identifying the factors that influence land price changes [10-12] and optimizing and improving research methods or econometric models focusing on land prices [13,14]. Some scholars have used land price data to explore the coordination and interaction between the scale of urban construction land, the degree of intensive land use and socioeconomic development from a macroscopic perspective $[3,15]$ and to explore the overall development status of residential land price and market health within a certain stage [16,17]. Studies on land prices on a microscopic scale, such as urban agglomerations and provinces, focus on regional differences and intercity differences $[4,18,19]$, selecting factors that affect the overall land price level of cities, such as land use potential [18], macroeconomics and policies $[18,19]$ and urban spatial structure [20]. The study of land prices on the microscopic scale focuses on the impact of land plot characteristics, location conditions, public service facilities and macro policies on land prices [21,22]. On this basis, some scholars have also focused on certain types of major factors and have analyzed in depth the mechanism of their influence on land prices $[23,24]$. Scholars have found that there may be significant land price differences between large cities in China, between cities in urban clusters or metropolitan areas, between counties within metropolitan areas and even between urban areas within the same city and that there is a general tendency for the land price gap between cities to widen gradually as the overall land price rises [9]. The combination of influencing factors such as the level of economic development, land supply capacity, population size and structure, transportation and location conditions leads to land price differences between cities and the dominant factors and combinations of characteristics that cause differences in land prices between different regions and classes of cities also vary [11,15,18].

Urban land prices, as a comprehensive expression of the level of urban development, have shown similar evolutionary patterns to those of economic development [25]. The current rapid development of Yangtze River Delta integration is characterized by the uncoordinated development of cities at all levels, poor factor flows, irrational flows and the inefficient allocation of resources due to inequitable distribution. Regional economic development depends on the optimal allocation of factors, which requires the appropriate flow of factors [5]. High-quality integrated regional development can promote the flow and reallocation of development factors such as industry, capital and population, which in turn promote the division of urban functions and industrial restructuring between regions, resulting in an increased spatial heterogeneity of land prices [26]. However, most of the current research on factor mobility has focused on its relationship with the economic scale, economic quality and coordinated regional economic development [27,28], but little has been done to explore the underlying mechanisms of factor mobility, resource allocation and land price changes in integrated regions. Although China's urban land market has generally improved in recent years, there are still problems of unbalanced development and a weak coordination of land prices in multiple industries [29]. Therefore, an in-depth 
analysis of the mechanisms and interrelationships between land prices and factors is a prerequisite for unraveling the "black box" of urban land price differentiation mechanisms.

The process of land price growth is always phased and volatile because of the many factors involved in the process of urban development, such as policies, socioeconomic conditions, the land market and the location [15]. However, the current academic community has mostly conducted static research in a single time dimension from the perspectives of sociology, economics and management, without taking into account spatial changes in land prices with temporal changes [24]. This limitation has made it difficult to portray the process of regional urban land price divergence and evolutionary trends. In integrated regions with close economic ties, a complete and universally meaningful inner mechanism and transmission path of land prices in multiple industries have not been generalized. Based on the above analysis, it is necessary to explore the laws and patterns of regional urban land price growth, divergence and evolution on a smaller spatial scale and over a longer time span, especially for integrated regions with close economic and social ties. Moreover, to clarify the spatial and temporal evolution of land prices, it is necessary to elaborate on the intrinsic correlation and reciprocal effects of factor flows and land price changes in integrated regions. It is also necessary to investigate the mechanisms of the influential factors in relation to urban land prices and the resulting differences in urban land prices within the region to enrich the research on the spatial differentiation of land prices in China and to provide Chinese cases for international comparisons.

\section{Theoretical Framework}

\subsection{Regional Factor Mobility and the Changes in the Land Prices of Multiple Industries}

For this study, factors are the input factors that form economic output, such as labor, capital, land and technology. In the process of flowing, factors are directional, which is manifested in profitability, proximity and aggregation [30]. Along with regional integration, the flow of various factors (human, logistics, capital, technology and information) is strengthened in the regional "flow space," which is in essence the process of optimizing the allocation of resource factors in spatial and geographical locations. Factor flows are driven by potential benefits and the size of those benefits is closely related to location conditions, resource endowment, infrastructure and the social environment [31]. Differences in the degree of regional socio-economic development cause differences in the efficiency of factor rewards, leading to unevenness in the distribution of resources and development opportunities [19], which in turn affects the direction of regional factor flows [32].

As an important carrier of urban development, the price of land is the basis of urban economic activities and factor flows. Changes in land prices can significantly drive the scale and direction of factor flows between regions and factor flows can have a facilitating or inhibiting effect on land prices [33]. From the perspective of industrial land, factor agglomeration generates economies of scale, saving the input of production factors and thus increasing the profitability of industrial production. From the perspective of commercial and residential land, factor agglomeration improves infrastructure such as transportation, communication and information networks, thus generating capital and market advantages and making a region suitable for economic development. Due to the "bull's-eye" orientation of factor flows and the agglomeration scale effect, advantageous areas attract a further inflow of development factors, enhancing regional economic strength and positively influencing land prices for residential and commercial services. In contrast, when the cost of production factors rises, the input of capital factors decreases, triggering a market slump and an imbalance between supply and demand, which eventually brings about a decrease in industrial value-added and labor productivity [34]. The decline in production efficiency brings about a reduction in core competitiveness in the market, forcing some manufacturing enterprises at the lower end of the value chain to move away to low-cost regions [35]. The outflow of production factors such as capital can lead to a sharp reduction in regional job opportunities and demand for labor, inhibiting the arrival of new residents and preventing local land prices from rising. The outflow of factors brings about a reduction in investment 
and consumption, reducing people's confidence in holding and purchasing residential assets. This decline in demand for housing leads to lower residential land prices [36], thus inhibiting the accumulation of factors of production such as capital and technology and bringing about a decline in industrial and commercial land prices.

\subsection{Mechanisms of Land Prices in Relation to the Differentiation of Multiple Industries in Integrated Regions}

The development process of the urban economy is essentially a process of continuous concentration and diffusion of capital, labor, technology and other factors in urban space [37]. In a market environment, enterprises tend to move to areas with infrastructure development conditions to meet their needs in relation to market development, resource allocation and division of labor [38]. Enterprises that are in decline or are unable to adapt to new technologies will gradually withdraw from central city markets and move to small and medium-sized cities in urban agglomerations, promoting the reallocation of factor resources between cities [31]. Factor flows and agglomeration directly affect the operational efficiency of urban social and economic systems, as well as the motivation and efficiency of external capital to invest in cities [39]. The massive inflow of people and enterprises, along with the improvement and optimization of infrastructure, speeds up the urbanization process and promotes the division of functions and rapid economic development in cities, thus attracting more factors [25]. Along with the continuous expansion of the local market, the concentration of factors leads to the rapid development of the corresponding area and an increase in land values. Given the limited supply of urban land, the resulting increase in demand causes an increase in land prices [40].

As economic development has path-dependent characteristics [30], the agglomeration economy and the scale effect of central cities strengthens the original location's advantages. The same-directional flow of various development factors triggers a "siphon effect" of the central cities on the peripheral areas, further hindering the free flow of labor, capital and other factors. Once the direction of factor flows is determined, inertia is generated, with land prices rising in areas where factors continue to flow in and falling in areas where factors flow out [39]. For example, high-grade cities such as Shanghai, Nanjing and Hangzhou have more public resources such as high-end education, medical care and science and technology; their positive economic development environment and good living conditions attract more high-end industries and foreign populations. The resulting siphon effect on the peripheral areas of the region accelerates the inflow of capital and technology factors and contributes to more rapid economic growth in cities. This core-fringe pattern of the regional economy is reinforced by the unequal allocation of resources [41], which ultimately affects urban land prices. As the flow of resource factors within regional integration accelerates, the trend of high-end development factors such as scarce capital, technology and talent gathering in a few core cities becomes more obvious and the difference in land price continues to expand through the cumulative cause-effect cycle effect.

In summary, disparities in the level of economic development lead to differences in resource allocation capacity between cities, prompting frequent movements of resource factors. The cross-regional mobility of elements brings about the reconfiguration of urban development factors, changing regional resource endowments and strengthening the professional division of labor and differences in service capabilities within the region [36]. This promotes the spatial reconfiguration of industries and the division of urban functions and facilitates the development of the regional economy and society. This development further accelerates the flow of factors and the resulting changes in regional economic growth give rise to spatial differences in land market supplies and demand, which are intrinsic to the spatial differentiation of urban land prices [42]. Therefore, regional land price differences are a comprehensive physical expression of the differences in the ability of cities to gather economic, human, social and administrative resources and urban land prices are determined by their own developmental levels and comprehensive resource allocation capabilities. From this analysis, the intrinsic mechanism of land price of multiple 
industries changes from the perspective of factor flows (Figure 1). This allows the dominant factors and combination characteristics of land price of multiple industries formation and change to be explored, clarifying the common influence mechanism of land price of multiple industries and land price differentiation.

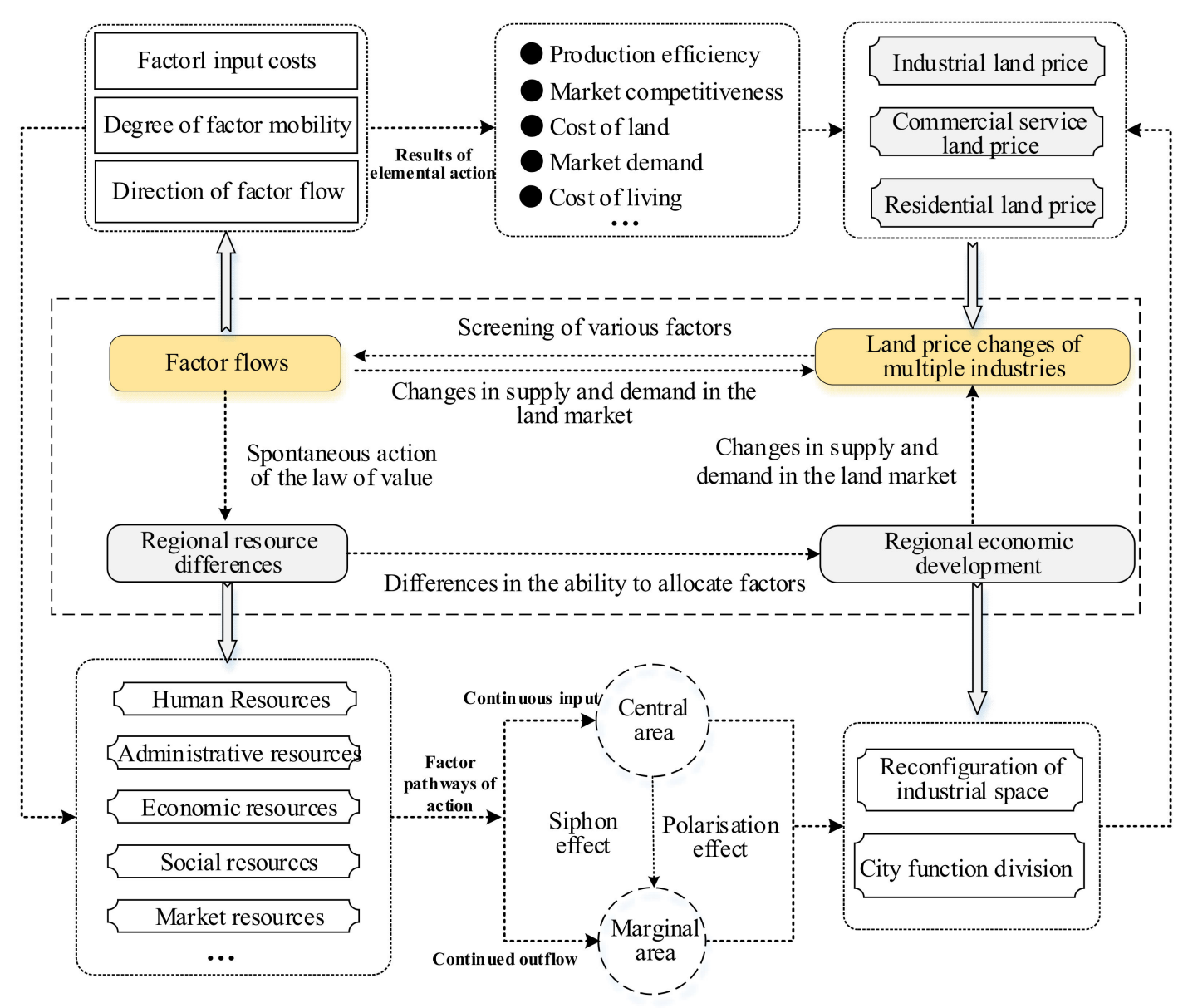

Figure 1. The analytical framework for the land prices of multiple industries differentiated from the perspective of factor flows.

\section{Area and Data}

\subsection{Study Area}

Because of the completeness of the structure of city systems and types within the Yangtze River Delta, the region covers cities with different functional positioning and development characteristics, which is highly representative. Unlike the Beijing-TianjinHebe region and the Guangdong-Hong Kong-Macao Greater Bay Area, which rely mainly on administrative resources or institutional advantages, the Yangtze River Delta has strong endogenous development dynamics of urban and township economies, higher land prices, faster growth rates and significant disparities. According to the current administrative division in early 2018 and the Outline of the Yangtze River Delta Regional Integrated Development Plan released in 2019, the Yangtze River Delta includes 41 prefecture-level cities and 306 counties in the Shanghai, Jiangsu, Zhejiang and Anhui provinces. Given its special location, Suzhou Industrial Park (Suzhou Industrial Park has a relatively good economic base, a large administrative jurisdiction and a large park area) is treated as a study unit in its own right, which gives a total of 307 study units in the study area (Figure 2). 


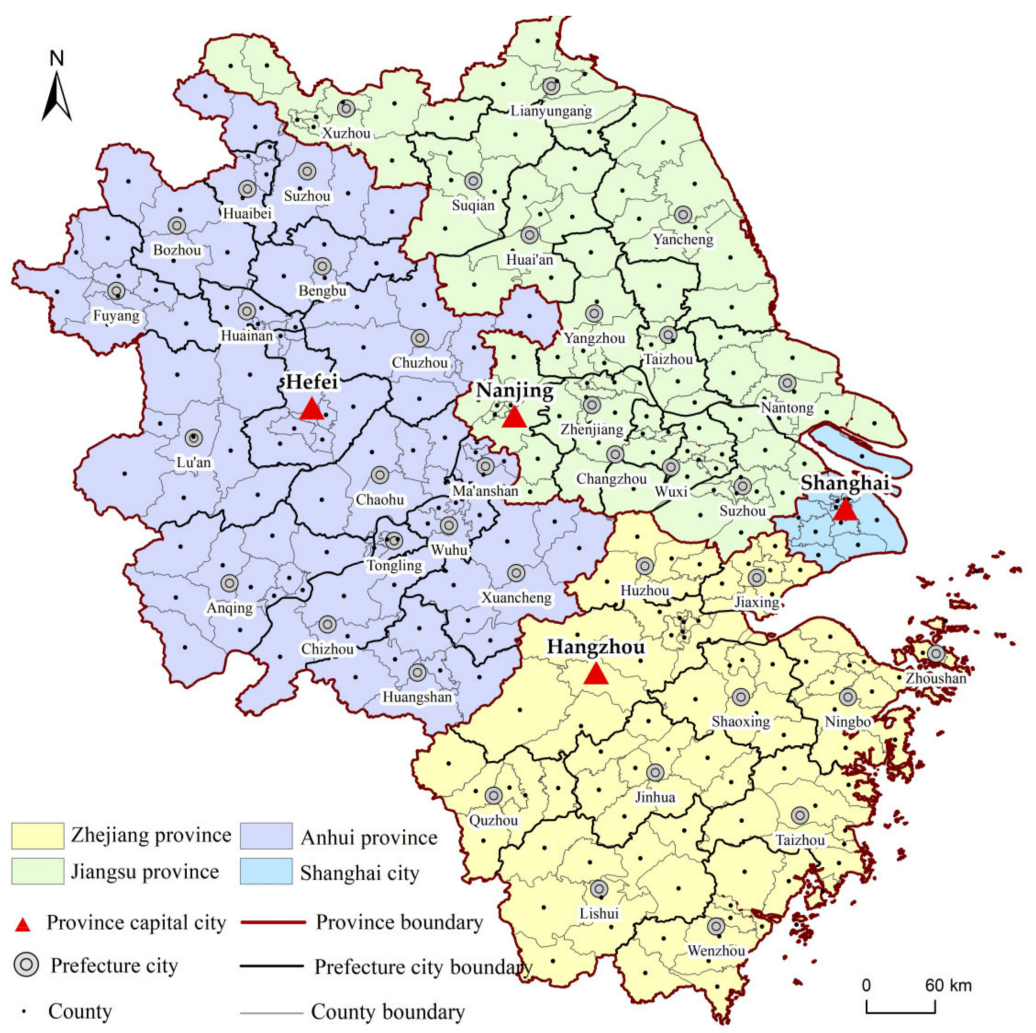

Figure 2. City boundary of the Yangtze River Delta.

\subsection{Data Sources and Processing}

The data for the study are divided into two parts. The data for residential, commercial service and industrial land disposal are published by the China Land Market Network (Source: http:/ / www.landchina.mlr.gov.cn accessed on 20 January 2019), including the area of the land and the plot ratio and transaction amount of each lot. During the study period, 185,055 residential, commercial service and industrial sites were granted within the study area, with a total area of $954,176 \mathrm{~m}^{2}$ (Table 1). To meet the requirements of the analysis and modeling, benchmark land price data from the China Urban Land Price Dynamics Monitoring System (Source: http:/ / www.landvalue.com.cn accessed on 28 January 2019) were used and the unit price of residential, commercial service and industrial land based on parcels of land was integrated into the county unit through level correction and removal of outliers [15]. A more accurate representation of the average land value of each county was enabled. To eliminate the average price bias that affected years with a small number of disposals, the land prices in some of the study units in years with fewer than 11 disposals were replaced by the average land prices for the next two years. As there are hardly any units with fewer than 7 years of land sales for each type of site, the replacement price would differ significantly from the true land price; the unit is therefore treated as a no-data area. After zonal comparison and rank order comparison [13], the results accurately reflected the level of market-based land prices of multiple industries in the Yangtze River Delta. The data for the macroeconomic indicators were obtained from the China Urban Statistical Yearbook, the China Regional Economic Statistical Yearbook, the China Urban Construction Statistical Yearbook, the Provincial Statistical Yearbooks and the Statistical Yearbooks of various cities from 2010 to 2018. The basic urban vector data were obtained from the National Public Service Platform for Geographic Information. 
Table 1. Overview of market-based land acquisitions in the study area, 2008-2018.

\begin{tabular}{|c|c|c|c|c|c|c|c|c|}
\hline \multirow{2}{*}{ Year } & \multicolumn{4}{|c|}{ Area Offered $\left(\mathrm{m}^{2}\right)$} & \multicolumn{4}{|c|}{ Number of Grants } \\
\hline & Residential & Commercial Service & Industrial & Subtotal & Residential & Commercial Service & Industrial & Subtotal \\
\hline 2008 & $36,029.16$ & $21,230.44$ & $28,350.60$ & $85,610.20$ & 1592 & 1176 & 2663 & 5424 \\
\hline 2009 & $26,689.81$ & $23,571.20$ & $25,201.46$ & $75,462.47$ & 2591 & 1721 & 6689 & 11,001 \\
\hline 2010 & $35,552.55$ & $27,911.41$ & $26,316.08$ & $89,780.04$ & 3795 & 3000 & 11,764 & 18,559 \\
\hline 2011 & $34,448.39$ & $26,940.55$ & $29,821.22$ & $91,210.16$ & 4299 & 3230 & 12,481 & 20,010 \\
\hline 2012 & $33,677.49$ & $33,473.09$ & $25,619.90$ & $92,770.48$ & 4093 & 3155 & 12,595 & 19,843 \\
\hline 2013 & $32,610.25$ & $31,284.21$ & $23,540.83$ & $87,435.29$ & 5682 & 4409 & 13,258 & 23,349 \\
\hline 2014 & $34,646.60$ & $28,810.12$ & $22,438.07$ & $85,894.79$ & 4889 & 3619 & 11,362 & 19,870 \\
\hline 2015 & $29,885.20$ & $24,345.83$ & $19,513.04$ & $73,744.07$ & 3836 & 3407 & 9680 & 16,923 \\
\hline 2016 & $34,330.43$ & $26,631.19$ & $23,173.42$ & $84,135.04$ & 3387 & 3330 & 8355 & 15,072 \\
\hline 2017 & $37,925.01$ & $29,441.29$ & $25,686.02$ & $93,052.32$ & 4431 & 2806 & 9453 & 16,690 \\
\hline 2018 & $37,223.08$ & $29,934.90$ & $27,922.97$ & $95,080.95$ & 4978 & 2715 & 10,621 & 18,314 \\
\hline Total & $373,017.97$ & $303,574.23$ & $277,583.61$ & $954,175.81$ & 43,566 & 32,568 & 108,921 & 185,055 \\
\hline
\end{tabular}

\subsection{Research Method}

\subsubsection{Spatial Auto Correlation}

This paper used the spatial auto-correlation method to measure whether there was a spatial correlation in the land price of multiple industries in 307 counties in the Yangtze River Delta from 2008 to 2018 and the common test statistic was the global Moran's I index [43], which is calculated as follows:

$$
I=\frac{\mathrm{n} \sum_{i=1}^{n} \sum_{j=1}^{n} W_{i j}\left(x_{i}-\bar{x}\right)\left(x_{j}-\bar{x}\right)}{\sum_{i=1}^{n} \sum_{j=1}^{n} W_{i j}\left(x_{i}-\bar{x}\right)^{2}}
$$

In Equation (1), $\mathrm{n}$ is the number of counties; $x_{i}$ and $x_{j}$ denote the transaction price of a certain type of land per unit in counties $i$ and $j$, respectively; $W_{i j}$ is the spatial weighting matrix of counties $i$ and $j$ and $I$ is between $(-1,1)$; when $I$ is positive and close to 1 , it means that this type of land price is concentrated; and when $\mathrm{I}$ is negative and close to -1 , it means that this type of land price is dis-persed; when I is 0 , it means that this type of land price has no correlation or is ran-domly distributed.

\subsubsection{Space Time Pattern Mining}

Space time pattern mining mainly includes the creation of space-time cubes and an analysis of emerging space-time hot spots. Emerging spatial-temporal hot spots use the temporal and spatial net CDF of the created spatial-temporal cubes as input to calculate Getis-OrdGi* statistics for each cubic bar by neighborhood distance and neighborhood time step values to identify hot and cold trends in the cubic data that develop over time and are statistically significant and to determine the temporal and spatial evolutionary patterns of land price of multiple industries [43].

\subsubsection{Spatial Panel Regression Model}

Based on spatial econometric theory, three types of models can be set up to analyze the mechanism of the spatial distribution of land prices of multiple industries in the YRD, namely, the Spatial Lag Model (SLM), the Spatial Error Model (SEM) and the Spatial Durbin Model (SDM). There may be three different interaction effects between the three types of land prices and the economic, demographic, social and market factors: the endogenous interaction effect, the interaction effect between error terms and the exogenous interaction effect, which corresponds to the three models of SLM, SEM and SDM in cross-sectional data, respectively [44]. Meanwhile, land prices in different regions and types are time-varying and such panel data can be divided into fixed-effect and random-effect models. The general expression of the SDM for integrating the spatial effects in time is: 


$$
Y_{i t}=\rho W Y_{i t}+\beta X_{i t}+\gamma W \bar{X}_{i t}+\delta W \varepsilon_{i t}+\mu_{i}+\lambda_{t}+u_{i t}
$$

In Equation (2), $t$ denotes the time dimension, $t=1,2 \ldots \mathrm{T} ; Y$ denotes the explanatory variable, which is a row vector; $\rho$ denotes the spatial auto-regressive coefficient; $W$ is the spatial weight matrix, here a first-order Queen adjacency matrix is used; $\beta$ is a kdimensional column vector, which denotes the coefficients of the $\mathrm{k}$ independent variables, $\mathrm{k}=1,2,3,4 ; \mathrm{X}$ is a $\mathrm{k}$-dimensional row vector, which denotes the observations of the $\mathrm{k}$ explanatory variables. $X$ is a variable matrix of explanatory variables; $W \bar{X}_{i t}$ reflects the average observations of spatially lagged explanatory variables in adjacent regions; $\gamma$ is used to measure the marginal effects of explanatory variables in adjacent regions on the dependent variable $Y ; \delta$ denotes the spatial auto-correlation coefficient; $\varepsilon$ denotes the spatial auto-correlation error term; $\mu_{i}$ denotes spatial fixed effects, which control all variables that are spatially fixed and do not vary over time; $\lambda_{t}$ denotes time fixed effects, which control all variables that are fixed in time and do not vary with space; and $u$ denotes the random error term. If $\delta, \gamma$ and $\rho$ are equal to 0 , the model is simplified to a general panel model; if $\rho \neq 0$ and $\delta$ and $\gamma$ are equal to 0 , the model is a spatial lagged panel model; and if $\delta \neq 0$ and $\gamma$ and $\rho$ are equal to 0 , the model is a spatial error panel model.

\section{Analysis of Spatial-Temporal Distribution Patterns of the Land Price of Multiple Industries}

\subsection{Overall Growth Characteristics of the Land Sale Prices of Multiple Industries}

A comparison of the land disposal prices of multiple industries (Figure 3) shows that the average annual prices in 307 counties in the Yangtze River Delta varied greatly, with the average price of residential land disposal continuing to show strong growth, rising from 6,825 RMB yuan per square meter in 2008 to 30,592 RMB yuan per square meter in 2018, an increase of $348 \%$. The average commercial service land price rose from 3,941 RMB yuan per square meter to 10,353 RMB yuan per square meter, an increase of 163\%. The average price of industrial land offered for sale grew more slowly, from $675 \mathrm{RMB}$ yuan per square meter to $870 \mathrm{RMB}$ yuan per square meter, an increase of $28 \%$. To attract investment, local governments lowered the industrial land rent, resulting in huge financial pressure on the commercial and residential land rent and they had to sell commercial and residential land at high prices. Meanwhile, this approach also achieved the goal of lowering enterprise costs and increasing public spending and accelerating local economic growth and urbanization. In terms of a time series of growth, residential and commercial land prices were significantly higher than industrial land prices. Residential land prices and commercial land use changed in a similar pattern, clearly showing three phases: small increases in 2008-2011 and 2012-2014 and rapid increases in 2015-2018. From 2008 to 2018, the ratio of commercial to residential areas expanded. Due to the extraordinary development of the real estate market and the break of the general law of the land economy, an increasingly serious phenomenon of "commercial to residential inversion" has been seen in the Yangtze River Delta region.

\subsection{Spatial Pattern of the Land Transfer Price in Multiple Industries}

The geometrical interval method was used to visualize the residential, commercial service and industrial land prices of 307 counties in the Yangtze River Delta in 2008, 2013 and 2018. It can be seen that residential land prices in the Yangtze River Delta were generally on the rise, with the consistently high-value areas of Shanghai, Nanjing and Hangzhou city followed by the neighboring provincial capitals and economically developed cities such as Suzhou, Wuxi, Changzhou and Ningbo city and then the lowest land prices in the peripheral, economically underdeveloped areas such as northern Jiangsu and northern Anhui province. From 2013 to 2018, the high-value areas gradually increased and clustered in northern Jiangsu and most of Anhui province and residential land prices in all counties increased significantly (Figure 4a). Spatially, commercial service land prices showed a similar distribution pattern to residential land prices (Figure $4 \mathrm{~b}$ ), with first- and second-tier 
cities such as Shanghai, Hangzhou, Nanjing and Suzhou city as the highest and a gradual decrease toward the periphery. Spatially, a multiple polar nucleus distribution that is characteristic of municipalities directly under the central government and provincial capitals extended outwards and the spatial divergence of land prices was basically consistent with the city system and levels of economic development. Overall, industrial land prices show a spatial pattern of gradual decline from the coastal areas of southeastern Zhejiang province to northern Jiangsu province, decreasing in turn from Shanghai city to Zhejiang province, Jiangsu and Anhui province. The high-value areas were clustered in the northern Zhejiang province (for example, Jiaxing and Shaoxing city) and in the southern Jiangsu province, whereas the low-value areas were distributed contiguously in northern Jiangsu and Anhui province (Figure 4c). This is closely related to the level of economic development in the Yangtze River Delta region, where demand for industrial land is high. Industrial land prices are high in the economically developed regions of southeastern Zhejiang and southern Jiangsu province, while the economies of southern Zhejiang and Anhui provinces are relatively underdeveloped and local governments offer industrial land at low prices to attract investment.

In terms of spatial-temporal changes in commercial service land prices, many counties, such as the Nanjing Qixia counties and Suzhou Wuzhong counties, became high land price areas in 2018. The proportion of medium and low land price counties decreased from $58 \%$ to $32 \%$ of the total and the number of low-value areas gradually decreased, showing the distribution characteristics of both spatial continuity and variability. In terms of spatial-temporal changes in residential land prices, the high-value areas gradually included northern Jiangsu, Anhui and eastern Zhejiang provinces, with most counties experiencing a rapid price growth at a rate of over 50\%. In 2018, numerous counties, including Hefei, Suzhou and Taizhou city became higher-value areas and the proportion of medium- and low-value counties decreased from $63 \%$ to $20 \%$ of the total. Only Shanghai, Nanjing, Hangzhou city and industrially developed areas such as Hefei city have higher commercial service land prices than residential land prices and the Yangtze River Delta region has seen residential land prices outstrip commercial land prices, contrary to the basic principle that the value of a commodity determines its price. The proximate cause of this is the rigid demands of China's rapid urbanization, which reflect the excessive speculation and overdrive of the real estate market. Compared to residential and commercial service land prices, industrial land prices have seen the least growth and inter year variation, with a more stable pattern of spatial divergence.

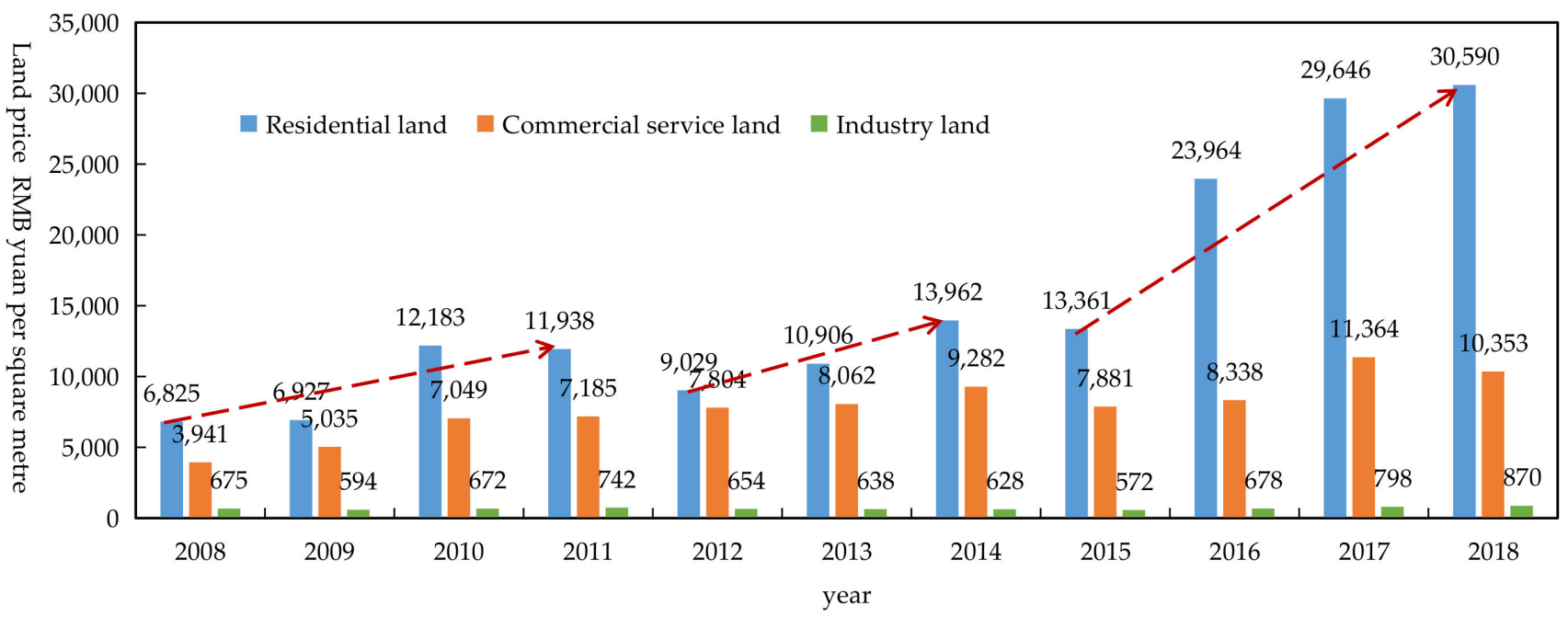

Figure 3. The growth process of the land price of multiple industries in the Yangtze River Delta counties, 2008-2018. 




Figure 4. (a-c) Spatially divergent patterns of the land price of multiple industries (a. residential, b. commercial service and c. industrial) in the Yangtze River Delta counties, 2008, 2013 and 2018.

\subsection{Spatial Correlation Characteristics of the Land Premiums for Multiple Industries}

The Moran's I values for land prices in multiple industries from 2008 to 2018 were all positive and passed the $1 \%$ significance test (Table 2 ). All of the land prices of multiple industries in the Yangtze River Delta counties had a more obvious positive spatial correlation (i.e., the similarity of land prices in neighboring counties was higher). The temporal changes in Moran's I indicate that the spatial agglomeration of industrial land prices diminished and had a significant spillover effect. In contrast, the difference between residential and commercial service land prices increased over time, with a significant polar- 
ization effect. The difference is reflected in the weak decline of Moran's I for commercial service land prices toward the end of the period, whereas Moran's I for residential land prices strengthened and after 2015, it continued to be higher than for commercial service land and industrial land prices. The reason for this is that residential land prices are mainly influenced by population concentration and per capital income, so the high-value areas are concentrated in economically developed cities such as northern Zhejiang and southern Jiangsu; this generates a strong spatial correlation of residential land prices and uncoordinated regional development. Commercial service land prices are subject to little intervention by government departments and are mainly influenced by the economic development gap, with obvious disparities between the commercial service land price levels in southern and northern Jiangsu and southeastern and western Zhejiang. Therefore, there is a small decline in spatial auto-correlation. Although industrial land is formally put up for sale by auction, it is common for the government to provide cheap industrial land and various preferential policies to decrease the prices of production factors in order to "attract investment". This artificially causes the industrial land price to vary greatly from year to year. Since industrial land is not fully competitive in the market, the price is less influenced by market-oriented factors. The spatial auto-correlation of industrial land prices is significantly weaker than that of commercial services and residential land prices.

Table 2. Moran's I value for residential, commercial service and industrial land prices.

\begin{tabular}{|c|c|c|c|c|c|c|c|c|c|c|c|c|}
\hline Land Price & Index & 2008 & 2009 & 2010 & 2011 & 2012 & 2013 & 2014 & 2015 & 2016 & 2017 & 2018 \\
\hline \multirow{3}{*}{ Residential } & Moran's I & 0.362 & 0.283 & 0.382 & 0.273 & 0.421 & 0.328 & 0.525 & 0.543 & 0.436 & 0.449 & 0.482 \\
\hline & $Z(\mathrm{I})$ & 10.963 & 9.063 & 11.614 & 8.932 & 12.114 & 6.857 & 15.736 & 16.012 & 15.375 & 13.309 & 14.865 \\
\hline & $P$ value & 0.001 & 0.001 & 0.001 & 0.001 & 0.001 & 0.001 & 0.001 & 0.001 & 0.001 & 0.001 & 0.001 \\
\hline \multirow[t]{3}{*}{ Commercial service } & Moran's I & 0.172 & 0.294 & 0.323 & 0.556 & 0.484 & 0.426 & 0.522 & 0.539 & 0.234 & 0.433 & 0.441 \\
\hline & $\mathrm{Z}(\mathrm{I})$ & 13.912 & 9.226 & 11.327 & 17.408 & 14.201 & 15.088 & 16.916 & 16.134 & 7.765 & 13.052 & 13.641 \\
\hline & $P$ value & 0.001 & 0.001 & 0.001 & 0.001 & 0.001 & 0.001 & 0.001 & 0.001 & 0.001 & 0.001 & 0.001 \\
\hline \multirow[t]{3}{*}{ Industrial } & Moran's I & 0.434 & 0.485 & 0.207 & 0.258 & 0.596 & 0.139 & 0.522 & 0.374 & 0.342 & 0.426 & 0.427 \\
\hline & $\mathrm{Z}(\mathrm{I})$ & 12.703 & 14.816 & 8.605 & 8.538 & 16.582 & 7.828 & 16.063 & 11.897 & 12.448 & 12.536 & 12.863 \\
\hline & $P$ value & 0.001 & 0.001 & 0.001 & 0.001 & 0.001 & 0.001 & 0.001 & 0.001 & 0.001 & 0.001 & 0.001 \\
\hline
\end{tabular}

\subsection{Evolution of the Spatial-Temporal Pattern of Land Offer Prices for Multiple Industrial Sites}

Using the spatial location of the price data for each region and county in the Yangtze River Delta as the $\mathrm{x}$ - and $\mathrm{y}$-axes and the transaction time as the $\mathrm{z}$-axis, a spatial-temporal bar with a distance interval of $10 \mathrm{~km}^{2}$ and a time step interval of one year was constructed to represent the change in residential land prices over time. The results of the Mann-Kendall trend test indicate that the overall trend in the price change across the Yangtze River Delta was incremental. A spatial-temporal hot spot analysis of 307 locations within $100 \mathrm{~km}$ shows that commercial service land prices were approximately $51 \%$ in cold spots and $32 \%$ in hot spots, whereas industrial land prices were approximately $49 \%$ in cold spots and $34 \%$ in hot spots. This indicates that commercial service land prices and industrial land prices were mainly falling. Residential land prices were more balanced, at approximately $41 \%$ in the hot spots and $37 \%$ in the cold spots, mainly rising. The patterns of cold and hot spots for the three types of land prices show clear geographical differences (Figure 5). Residential land prices were concentrated in Shanghai, Nanjing and Hangzhou City, with the lowest prices in the peripheral, less economically developed regions and counties in northern Jiangsu and northern Anhui province. The main areas in which land prices were evolving were intensifying cold spots and consecutive hot spots (Figure 5a). Commercial service land price hot spots were concentrated in the central Yangtze River Delta and the eastern coastal region, with consecutive cold spots, intensifying cold spots, consecutive hot spots and intensifying hot spots as the main types of evolution (Figure $5 b$ ). Industrial land price hot spots were the least numerous, with consecutive hot spots and intensifying hot spots dominating and new and sporadic hot spots gradually appearing to the west. Southern Zhejiang, Jiangsu and Anhui provinces were all cold spot clusters (Figure 5c). 


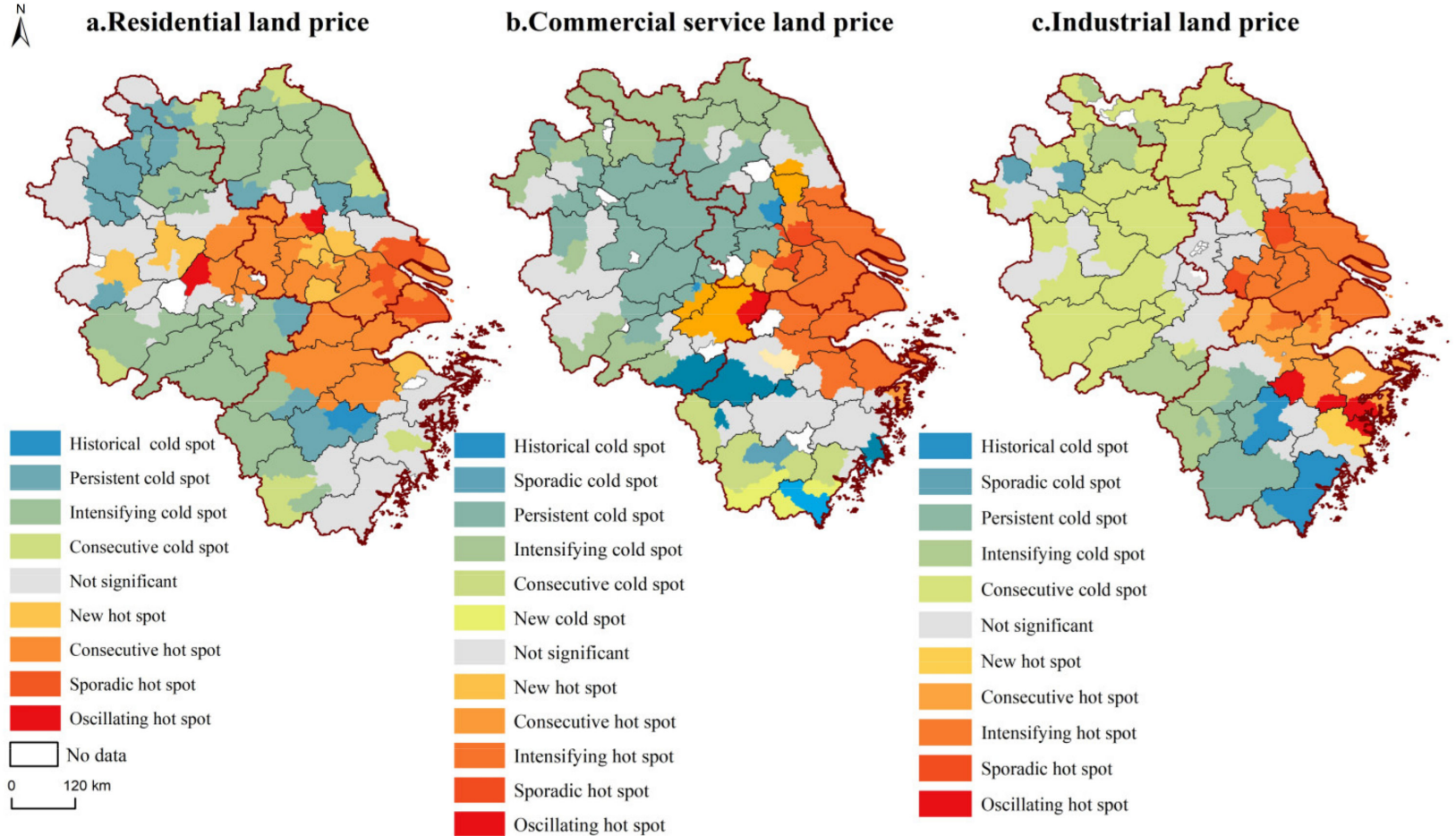

Figure 5. $(\mathbf{a}-\mathbf{c})$ Analysis of the spatial-temporal patterns of the land price of multiple industries (a. residential, b. commercial service and c. industrial) in the Yangtze River Delta counties, 2008-2018.

Overall, the hot spots for the three types of land were distributed in an obvious concentrated contiguous pattern in the eastern coastal areas where southern Jiangsu province, Shanghai city and northern Zhejiang province are located and in the central Yangtze River Delta, showing a spatial pattern in line with the degree of regional economic development. The spatially widening land price differences are reflected in the leading position of Shanghai city and the sub-central position of Nanjing and Hangzhou city, with the land price gap between Zhejiang and southern Jiangsu province, Anhui and northern Jiangsu province becoming more pronounced. The reason for this is that as cities continue to expand, factors within the Yangtze River Delta continue to cluster in the core cities of Nanjing, Hangzhou and Shanghai city. Due to the economies of scale effect, compared to peripheral areas, cities with developed economies and high administrative levels have greater benefits in terms of population, industry and economic resource concentration, with greater investment demand in the commercial service and residential markets; high-value areas in local counties are evident. For example, Yiwu city, the largest distribution center for small commodities in China, has good commercial trade conditions that promote regional economic development and high rates of employment, prompting a significant increase in land prices. Moreover, regional central cities or provincial capitals have obvious location advantages; they are often affected by policy preference, they can often obtain more land use indicators and the land price is increased due to the impact of land supply. First, northern Jiangsu, southern Zhejiang and Anhui provinces are economically less developed, resulting in less demand for land and lower land prices. Second, they belong to the population outflow region, where industrial development is very weak. With the loss of demographic dividends and industrial support, the stimulating effect of real estate development and investment on land prices weakens. Correspondingly, the driving force decreases significantly compared with Shanghai city and other eastern coastal areas, northern Zhejiang province and other economically developed cities and land prices decrease. 


\section{Analysis of the Factors Influencing the Spatial-Temporal Differentiation Pattern of Land Prices}

\subsection{Theoretical Analysis of Factors That Influence Land Prices and a Selection of Indicators}

The supply and demand of land is the base point for land price generation and the contradiction between supply and demand drives the spatial pattern of the land price hierarchy. Industry, population, policy and other factors can indirectly influence urban land prices by affecting urban land supply or demand. The factors influencing land price in the existing empirical literature can be divided into two categories: urban factors and parcel factors. Urban factors mainly include urban economic factors (Gross Domestic Product (GDP), income level, industrial structure, etc.), demographic factors (population density, population size, etc.) and social factors (medical level, education level, public transportation level, etc.) $[4,17,18]$, which influence the overall land price level of cities and are used to analyze intercity land price differences; plot factors have a significant impact on intra-city micro-transaction land prices, mainly including plot characteristics themselves (floor area ratio, area offered for sale, etc.) and external government intervention [20,21]. Considering the relationship between urban land supply and demand, China's land market system and the macroeconomic background, this paper takes the three-dimensional driving theory of land "demand + supply + market" as the entry point of inter-regional urban land price influencing factors, combines urban factors and plot factors and selects land prices from economic, demographic, social, administrative and market aspects. From 2008 to 2018, 14 indicators were selected as independent variables from five aspects, economic, demographic, social, administrative and market, to investigate the reasons for the spatial variation of residential, commercial service and industrial land prices in the Yangtze River Delta counties (Table 3).

Table 3. Indicator system of spatial differentiation factors influencing land price of multiple industries in Yangtze River Delta regions and counties.

\begin{tabular}{|c|c|c|c|c|}
\hline Variable Type & Feature Variables & Specific Indicator & Calculation Method & Units \\
\hline \multirow[t]{5}{*}{ Economic factors } & Economic strength & Per capital GDP & GDP/resident population & RMB yuan per person \\
\hline & Level of consumption & $\begin{array}{l}\text { Total retail sales of consumer } \\
\text { goods per capital }\end{array}$ & $\begin{array}{l}\text { Retail sales of consumer } \\
\text { goods/resident population }\end{array}$ & RMB yuan per person \\
\hline & Industrial structure & Proportion of tertiary sector & Tertiary sector output/GDP & Proportion \\
\hline & & Tertiary industry output & Tertiary industry output & Million \\
\hline & & $\begin{array}{l}\text { Ratio of secondary production to } \\
\text { tertiary production }\end{array}$ & $\begin{array}{c}\text { Secondary industry output } \\
\text { value/tertiary industry output } \\
\text { value }\end{array}$ & Proportion \\
\hline \multirow[t]{3}{*}{ Population factors } & Population density & Resident population density & $\begin{array}{l}\text { Total resident population/area of } \\
\text { the counties }\end{array}$ & $\begin{array}{l}\text { Number of persons } \\
\text { per square kilometer }\end{array}$ \\
\hline & Level of urbanization & Urban population Proportion & $\begin{array}{l}\text { Urban resident population/total } \\
\text { resident population }\end{array}$ & Proportion \\
\hline & $\begin{array}{l}\text { Demographic } \\
\text { attractiveness }\end{array}$ & $\begin{array}{c}\text { Proportion of resident } \\
\text { population }\end{array}$ & $\begin{array}{l}\text { Resident population/household } \\
\text { population }\end{array}$ & Proportion \\
\hline \multirow[t]{2}{*}{$\begin{array}{l}\text { Administrative } \\
\text { factors }\end{array}$} & City class & City class & $\begin{array}{l}\text { City class of the city in which the } \\
\text { counties located }\end{array}$ & $\begin{array}{l}1-5 \text { Categorical } \\
\text { variables }\end{array}$ \\
\hline & Land use intensity & Maximum volume ratio & $\begin{array}{l}\text { Maximum floor area ratio for land } \\
\text { to be sold by auction }\end{array}$ & None \\
\hline \multirow[t]{2}{*}{ Social factors } & Public service inputs & Financial expenditure per capital & $\begin{array}{l}\text { Local financial } \\
\text { expenditure/resident population }\end{array}$ & RMB yuan per person \\
\hline & Infrastructure supply & $\begin{array}{c}\text { Average land value of fixed asset } \\
\text { investment }\end{array}$ & $\begin{array}{l}\text { Amount of fixed asset } \\
\text { investment/area of the counties }\end{array}$ & $\begin{array}{l}\text { Million yuan per } \\
\text { square kilometer }\end{array}$ \\
\hline \multirow[t]{2}{*}{ Market factors } & $\begin{array}{l}\text { Degree of land } \\
\text { marketability }\end{array}$ & $\begin{array}{c}\text { Proportion of area offered for } \\
\text { auction }\end{array}$ & $\begin{array}{c}\text { Area of land sold by auction/total } \\
\text { area of land sold }\end{array}$ & Square meters \\
\hline & $\begin{array}{c}\text { Real estate investment } \\
\text { density }\end{array}$ & $\begin{array}{l}\text { Land average property } \\
\text { development investment }\end{array}$ & $\begin{array}{c}\text { Investment in property } \\
\text { development/administrative area }\end{array}$ & $\begin{array}{l}\text { Million yuan per } \\
\text { square kilometer }\end{array}$ \\
\hline
\end{tabular}

In this paper, population density, urbanization level and population attractiveness reflect the potential of demand for land; GDP per capital, the proportion of tertiary industry output value and gross value of tertiary industry reflect the level of economic development and industrial structure; the proportion of secondary and tertiary industry output value is 
used as an indicator of industrial structure upgrading; total consumption of social retail goods characterizes the consumption ability of residents; and city class characterizes the scale of cities. In addition, land price level is also improved by the capital addition of fiscal expenditure, the intensive use of land and the improvement of urban infrastructure and public services [45]. Therefore, the proportion of land area and plot ratio of land sold by auction reflects the scale of land supply and intensity of development and utilization; the average amount of real estate development investment reflects the market investment density or speculative demand and the degree of market competition; and the average financial expenditure of land reflects the investment in urban infrastructure and public services.

\subsection{Spatial Panel Regression Analysis}

\subsubsection{Model Identification and Fitting Results}

The spatial panel regression models for each of the three types of land prices were constructed using residential, commercial service and industrial land prices as dependent variables and 14 indicators were selected as independent variables. SPSS software was used to test the independent variables for multi collinearity and the variables with VIF values greater than 10 were excluded by the maximum variance expansion factor method, namely, per capital fixed asset investment, per capital total retail sales of social consumer goods and per capital fiscal revenue. Subsequently, the remaining 11 variables were tested for significance using the great likelihood estimation method and the variables that did not pass the significance test in the three land value categories were excluded using the stepwise regression method with forwards steps. To reduce the effect of heteroskedasticity, both dependent and independent variables were taken as natural logarithms. For the selection of spatial panel models, Lagrange multipliers (LM Lag and LM err) and their robustness (R-LM lag and R-LM err) were used to make judgments. From the test results in Table 4, the statistics of LMLAG and LMERR for commercial service, residential and industrial land prices pass the significance test and the statistics of R-LM lag and R-LM err are significant at the $1 \%$ test level. According to Anselin's discriminant criteria, it is more appropriate to choose the SDM to analyze the influencing factors of the three types of land prices in the Yangtze River Delta. The SLM and SEM were constructed based on the spatial adjacency matrix and their results showed that both the Wald and LR tests passed the significance test at the $1 \%$ level, while rejecting the original hypothesis that the SDM could not be reduced to the SLM and SEM. According to the Hausman test results (Table 4), the random effects model was rejected, so the fixed effects SDM model was used for fitting estimation.

Table 4. Diagnostics for spatial effect.

\begin{tabular}{cccc}
\hline Test Method & Residential & Commercial Service & Industrial \\
\hline Lagrange multiplier (error) & $4.080^{* *}$ & 0.539 & $14.167^{* * *}$ \\
Robust LM (error) & $9.441^{* * *}$ & $42.847^{* * *}$ & $4.191^{* *}$ \\
Lagrange multiplier (lag) & $25.480^{* * *}$ & $16.727^{* * *}$ & $13.373^{* * *}$ \\
Robust LM (lag) & $30.841^{* * *}$ & $58.968^{* * *}$ & $3.397^{*}$ \\
Wald spatial lag & $72.29^{* * *}$ & $52.64^{* * *}$ & $58.84^{* * *}$ \\
Wald spatial error & $73.34^{* * *}$ & $58.52^{* * *}$ & $62.50^{* * *}$ \\
LR spatial lag & $69.65^{* * *}$ & $51.27^{* * *}$ & $57.13^{* * *}$ \\
LR spatial error & $71.67^{* * *}$ & $57.62^{* * *}$ & $61.65^{* * *}$ \\
Hausman test probability & $49.61^{* * *}$ & $28.92^{* * *}$ & $22.44^{* * *}$
\end{tabular}

Note: ${ }^{* *},{ }^{* *}$ and ${ }^{*}$ indicate $1 \%, 5 \%$ and $10 \%$ significance levels, respectively.

The fixed-effects model was further divided into three effect models: period fixed, spatial fixed and period-spatial bidirectional fixed. For the sake of prudence, the no-fixedeffects, period fixed-effects, spatial fixed-effects and bidirectional fixed-effects SDM models were estimated separately and the estimated results were compared and analyzed. From the analysis results (Table 5), both the log likelihood (Log-L) and the goodness of fit $\left(\mathrm{R}^{2}\right)$ indicated that the results for the time fixed effect were the best fit (model 1, model 2, model 
3 and model 4 are no fixed effect, time fixed effect, spatial fixed effect and time-space bifixed effect, respectively).

Table 5. Model estimation results for traditional hybrid panel data.

\begin{tabular}{|c|c|c|c|c|c|c|c|c|c|c|c|c|}
\hline \multirow[t]{2}{*}{$\begin{array}{l}\text { Specific } \\
\text { Indicator }\end{array}$} & \multicolumn{4}{|c|}{ Residential } & \multicolumn{4}{|c|}{ Commercial Service } & \multicolumn{4}{|c|}{ Industrial } \\
\hline & Model 1 & Model 2 & Model 3 & Model 4 & Model 1 & Model 2 & Model 3 & Model 4 & Model 1 & Model 2 & Model 3 & Model 4 \\
\hline $\begin{array}{l}\text { City class } \\
\text { Resident }\end{array}$ & $0.472 * *$ & $0.451 * *$ & 0.136 & $0.231^{* *}$ & $0.184 *$ & $0.132 * *$ & $0.106^{*}$ & $0.131 *$ & $0.625^{* * *}$ & $0.536^{* * *}$ & $4.358^{* *}$ & 1.851 \\
\hline $\begin{array}{l}\text { population } \\
\text { density }\end{array}$ & $0.214^{* *}$ & $0.285^{* * *}$ & 0.068 & $0.103 *$ & $0.145^{*}$ & $0.482 * * *$ & -0.031 & -0.040 & $0.139 * *$ & $0.125^{* *}$ & $0.186^{* * *}$ & $0.188^{* * *}$ \\
\hline $\begin{array}{l}\text { Per capital GDP } \\
\text { Ratio of } \\
\text { secondary }\end{array}$ & $0.123 * *$ & $0.142 * *$ & $0.057^{* *}$ & $0.159^{* * *}$ & & & & & $0.679 * * *$ & $0.642 * * *$ & -0.062 & -0.113 \\
\hline $\begin{array}{l}\text { production to } \\
\text { tertiary } \\
\text { production }\end{array}$ & & & & & & & & & $0.710 * * *$ & $0.709^{* * *}$ & -0.044 & -0.054 \\
\hline $\begin{array}{l}\text { Proportion of } \\
\text { tertiary sector }\end{array}$ & $0.405^{* * *}$ & $0.498^{* * *}$ & 0.192 & $0.256^{*}$ & 0.233 * & $0.366^{* *}$ & -0.025 & -0.033 & $0.132^{* * *}$ & $0.131 * * *$ & -0.056 & -0.099 \\
\hline $\begin{array}{l}\text { Land average } \\
\text { property } \\
\text { development } \\
\text { investment }\end{array}$ & $0.182 * *$ & $0.198^{* *}$ & $0.095 *$ & -0.030 & $0.324^{* * *}$ & $0.270^{* * *}$ & $0.493^{* * *}$ & $0.495^{* * *}$ & $0.153 * * *$ & $0.141 * *$ & $0.122 * * *$ & $0.127^{* * *}$ \\
\hline $\begin{array}{c}\text { Financial } \\
\text { expenditure per } \\
\text { capital }\end{array}$ & $0.109 * *$ & $0.155^{* * *}$ & $0.076^{*}$ & $0.089 *$ & $0.195^{* * *}$ & $0.292 * * *$ & $0.104^{* * *}$ & $0.203 * * *$ & $0.200 *$ & $0.296 * *$ & -0.024 & -0.028 \\
\hline $\begin{array}{l}\text { proportion of } \\
\text { area offered for } \\
\text { auction }\end{array}$ & $0.479 * *$ & $0.457^{* * *}$ & $0.445^{* * *}$ & $0.497^{* * *}$ & $0.436^{* * *}$ & $0.439 * * *$ & $0.564 * * *$ & $0.551 * *$ & & & & \\
\hline $\begin{array}{c}\text { Maximum } \\
\text { volume ratio }\end{array}$ & & & & 0.060 * & $0.199 *$ & $0.286^{* * *}$ & $0.264^{* * *}$ & $0.281^{* * *}$ & $0.702^{* * *}$ & $0.687^{* * *}$ & $1.032^{* * *}$ & $1.035^{* * *}$ \\
\hline $\mathrm{R}^{2}$ & 0.650 & 0.653 & 0.312 & 0.336 & 0.548 & 0.630 & 0.531 & 0.529 & 0.589 & 0.645 & 0.361 & 0.492 \\
\hline Log-L & 4112.186 & 4434.850 & 4025.325 & 4063.210 & 2601.127 & 2856.231 & 2780.037 & 2750.287 & 4294.826 & 4596.240 & 3957.253 & 4296.932 \\
\hline
\end{tabular}

Note: ${ }^{* * *}, * *$ and ${ }^{*}$ indicate $1 \%, 5 \%$ and $10 \%$ significance levels, respectively.

\subsubsection{Analysis of the Spatial Effects of the Influencing Factors}

After excluding the insignificant influencing factors by stepwise regression for each of the three types of land prices, three time-fixed effects regression models were established for residential, commercial services and industrial services (Table 6). The fitting results were all above 0.6 . The three types of land prices were positively influenced by different combinations of factors and the spatial spillover effect of commercial service land prices was insignificant. Observing the intensity (coefficient) and significance test ( $\mathrm{p}$ value) of each factor, it was found that the factors with greater influence on residential land price were city level, share of tertiary sector, population density and proportion of area offered for auction and all factors have positive spillover effects on land price in surrounding counties except city level and plot ratio. The main factors affecting the land price of commercial services were population density, financial expenditure and the proportion of area offered for auctions. All factors were insignificant, except for the positive spatial spillover effect of fiscal expenditure on neighboring counties and the negative spatial spillover effect of population density on neighboring counties. The main factors affecting industrial land were urban class, GDP per capital, the ratio of secondary production to tertiary production and plot ratio and all indicators had positive spillover effects except for the ratio of secondary production to tertiary production. The correlation between the changes in land price of commercial service and residential land and each macroindicator over time is consistent with the general rule of market economy and the factors affecting commercial and residential land price and the magnitude of their effects have strong similarities. 
Table 6. Model estimation results for SDM.

\begin{tabular}{|c|c|c|c|c|c|c|}
\hline \multirow[t]{2}{*}{ Specific Indicator } & \multicolumn{2}{|c|}{ Residential } & \multicolumn{2}{|c|}{ Commercial Service } & \multicolumn{2}{|c|}{ Industrial } \\
\hline & Coefficient & $\begin{array}{l}\text { Lagging Term } \\
\text { Coefficient }\end{array}$ & Coefficient & $\begin{array}{l}\text { Lagging Term } \\
\text { Coefficient }\end{array}$ & Coefficient & $\begin{array}{l}\text { Lagging Term } \\
\text { Coefficient }\end{array}$ \\
\hline City class & $0.451 * *$ & -0.587 & $0.132 * *$ & -0.223 & $0.536^{* * *}$ & $0.375 * *$ \\
\hline Resident population density & $0.285^{* * *}$ & $0.170^{* * *}$ & $0.482 * * *$ & $-0.476^{* *}$ & $0.125 * *$ & $0.334 * *$ \\
\hline Per capital GDP & $0.142 * *$ & $0.096 * *$ & & & $0.642 * * *$ & 0.112 \\
\hline $\begin{array}{l}\text { Ratio of secondary production to } \\
\text { tertiary production }\end{array}$ & & & & & $0.709 * * *$ & $-0.449 * *$ \\
\hline Share of tertiary sector & $0.498^{* * *}$ & $0.412 * * *$ & $0.366^{* *}$ & 0.354 & $0.131^{* * *}$ & $0.375^{*}$ \\
\hline $\begin{array}{l}\text { Ratio of secondary production to } \\
\text { tertiary production }\end{array}$ & $0.198 * *$ & $0.011^{* *}$ & $0.270 * * *$ & -0.062 & $0.141^{* *}$ & 0.010 \\
\hline Share of tertiary sector & $0.155^{* * *}$ & $0.116 *$ & $0.292 * * *$ & $0.497^{* * *}$ & $0.296 * *$ & 0.001 \\
\hline $\begin{array}{l}\text { proportion of area offered } \\
\text { for auction }\end{array}$ & $0.457^{* * *}$ & $-0.315^{* * *}$ & $0.439 * * *$ & 0.014 & & \\
\hline Maximum volume ratio & & & $0.386^{* * *}$ & -0.387 & $0.687^{* * *}$ & -0.128 \\
\hline $\mathrm{R}^{2}$ & 0.653 & & 0.600 & & 0.605 & \\
\hline Log-L & 4434.850 & & 2856.231 & & 4596.240 & \\
\hline Rho (Lambda) & $0.146^{* * *}$ & & 0.002 & & $0.141^{* * *}$ & \\
\hline
\end{tabular}

Note: ${ }^{* * *},{ }^{* *}$ and ${ }^{*}$ indicate $1 \%, 5 \%$ and $10 \%$ significance levels, respectively.

Specifically, population density has a significant positive relationship with commercial service and residential land prices, which has a negative spillover effect on commercial service land prices in neighboring cities. The agglomeration effect will widen the regional economic gap between the in-migration and out-migration areas, which in turn will have a negative impact on the retail market in the out-migration areas, resulting in lower land prices. In terms of industrial factors, the higher the proportion of tertiary industries in modern urban functions, such as finance and construction, the higher the land price level, while the land prices of small and medium-sized municipalities with retail, traditional service, heavy industry and manufacturing industries as the leading industries are relatively cheaper, so the impact coefficients of the proportion of tertiary industries on commercial service and residential land prices reach 0.498 and 0.366 , respectively. The impact coefficient of the ratio of secondary and tertiary industries on industrial land prices is as high as 0.7 and has a negative impact on neighboring areas. With the upgrading of industrial structure from secondary to tertiary industries, the distance between industrial production and the consumer market is closed, which in turn leads to the change of land supply and demand structure and raises the local industrial land price level, while the neighboring areas may take up the transferred low value-added and low productivity industries, hindering the land price increase [46]. Fiscal expenditure and city class have significant positive effects on the three types of land prices in local and neighboring areas. Fiscal spending can reflect the intensity of regional infrastructure construction and public service investment and increase the efficiency of the urban economy and attract enterprises and capital inflow [47], which will increase the return of capital invested in land and the resulting differential land rent is the key factor of land price increase; The amount of investment in real estate development not only reflects the strong demand for land and the intensity of competition from the side, but also directly determines the amount of capital that enters the land market through this segment of real estate development in this city, which influences the land price trend to a greater extent. However, since real estate regulation policies have a lagging effect on the performance of land prices, the influence coefficient is small.

Since the supply of land in the primary market of land transactions is monopolized by the government, the price of land concessions is influenced by the level of regional economic development and policies and these factors are directly linked to the administrative level of cities; the higher the city level, the greater the investment in urban development and the policy facilitation and strategic resources obtained from higher levels and the higher the corresponding land value [48]. In addition, due to the land supply, provincial capital cities or regional center cities tend to obtain more land targets, while other cities have relatively fewer targets, which directly affects the urban land supply and thus the land price. In 
addition, the coefficients of the ratio of the area offered for auction to commercial service and residential land prices are all above 0.4 , indicating that the lower the ratio of land offered for auction, the higher the urban land prices. The coefficient of the spatial lag term is negative, so the proportion of local auctioned area has a negative influence on the land price in the surrounding counties. This indicates that the introduction of the auction system in China at the present stage has increased the real price of land and, to some extent, the price of operating land due to the competition effect [20]. The coefficient of the effect of per capital GDP on residential land prices is small, which shows that the indirect demand for urban land formed by residents purchasing commercial service houses is not the main factor of residential land price rise. In contrast, the coefficient of influence of GDP per capital on industrial land price is larger because the demand for industrial land is often driven by market economic demand and urban GDP per capital represents the economic level and purchasing power of cities, which provides a broad market for product sales [48]. The impact of the plot ratio on commercial service and industrial land prices is achieved by changing the land use yield. Plots with higher capacity limits have more economic gains per unit of land area and therefore higher land prices.

\section{Discussion}

Based on the spatial-temporal transmission and reciprocal feedback mechanism between land prices and factor flows, this paper identifies the dominant factors of spatialtemporal divergence in land prices of multiple industries and summarizes the formation mechanism of land prices in multiple industries. To better promote the goal of integrated regional development, recommendations for urban land price regulation are targeted from the perspective of factor flow and allocation.

\subsection{Influence Mechanism of the Land Price Related to the Differentiation of Multiple Industries Based on Factor Mobility}

According to the results of the spatial panel regression model, the five factors of population density, the proportion of three industries, per capital financial expenditure, real estate investment and the proportion of area offered for auctions have different degrees of influence on the three types of land. Therefore, this paper categorizes them into four aspects, administrative dominance, industrial agglomeration, population mobility and market competition to illustrate the influence mechanism of factor mobility on the land price of multiple industries in the Yangtze River Delta.

\subsubsection{Dominant Effect of City Governments on Land Price Formation}

The government holds the right to allocate resource elements and becomes the core force that dominates the change in land price of multiple industries. As the city government has strong resource allocation ability, in addition to dominating administrative and social resources, it also influences the direction of regional economic development and population flow, playing a dominant and guiding role over economic, human and social resources and has absolute dominance over land price changes [49]. The influence of administrative factors on land prices is often achieved through urban planning, infrastructure allocation and land use policy regulation to guide urban development activities, essentially optimizing the combination of urban industries, land and capital [50]. Local governments attract industries to land through land acquisition and concession mechanisms that control the price of land in the region; through the expansion of production scale, the flow and relocation of production factors to promote industrial development, boost local economic growth and attract population inflow, thus increasing the demand for land for various industries and promoting urbanization, indirectly promoting the level of residential, commercial service and industrial land prices [51]. Apart from this, since land value is the capitalization of future land rent, the improvement of infrastructure and public services and the optimization of urban environment provided by the government through fiscal 
expenditure in future periods may be capitalized into the value of land or housing in the current period, which to a certain extent contributes to the increase in land price [52].

\subsubsection{Curing Effect of Industrial Development on Land Price Patterns}

As an important representation of the regional economic development level, the industrial structure has a solidifying effect on the spatial pattern of land prices in multiple industries in the Yangtze River Delta. Industrial structure adjustment and upgrading can change urban functions and thus reshape the structure of land use, which is a direct driving force for the rapid growth of urban land use in the current stage [53]. With the optimization of industrial structure, secondary industries with low value-added and low productivity are forced to move to areas with lower land prices, while knowledgeintensive and high value-added industries are concentrated in developed cities, thus bringing a series of economic effects such as accumulation of high-quality human capital, increase in residents' income, technological innovation and industrial agglomeration [54], which have positively contributed to the land price of multiple industries. At the same time, the growing development of secondary and tertiary industries and the consequent population migration inevitably require the provision of more urban production and living space [37], which increases the demand for housing, factory buildings, office buildings and business premises, promoting the rise of commercial service real estate, residential and industrial land prices. From the perspective of regional integration, regional cooperation and industrial linkages between local governments in areas with high levels of industrial synergy and agglomeration are becoming increasingly close. Under the dual effect of economies of scale and scope, industrial development among cities will drive the spatial pattern of land prices in the Yangtze River Delta to stabilize, with a "fixed effect" of spatial differentiation in urban land prices [55].

\subsubsection{Competitive Effects of Land Price Increases under Market Mechanisms}

The accelerated economic operation makes urban land prices depend not only on supply and demand but also on speculative behavior, expected returns on land prices and the degree of competition [56]. Since the determination of land prices is determined by the induced demand for land as a factor of production and influenced by factors such as economic development expectations and housing price expectations, the land purchase and sale market contain more speculative behaviors [57]. Under the premise of controlling the total amount of urban construction land, the government has a limited supply of various types of land and the scarcity of land resources has led developers to intensify their competition for land resources. The competitive growth of real estate investment drives a large amount of capital investment as a direct driver of land price increases [58]. In addition, in the land market mechanism, the local government supply monopoly and the competitive demand side have an important impact on land transaction prices. From the point of view of the land market transfer method, "auction and listing" introduces a market-oriented competition mechanism and promotes the smooth flow of information elements so that the land price is determined by the bidding among developers in the market, which may have a great impact on the expected revenue and risk of developers and is conducive to the optimal allocation of land resources in the competition [59], which to a certain extent reveals the real price of land and allows the land supply and demand situation to be better reflected by market signals, influencing the government's land supply behavior.

\subsubsection{Mediating the Transmission Effect of Population Movement on Land Price Changes}

Population movement, as an intermediary mechanism between industry, administration and the market, brings about changes in land prices by influencing land supply and demand. The expansion or reduction in population size and changes in population structure may become decisive factors in determining urban land markets in the long run [60]. In the process of urbanization, the higher the population density is, the greater the potential housing demand. Real estate developers, as developers and builders of land, can keenly 
perceive the market demand for land and effectively integrate various resources, such as credit funds and administrative permits, to rapidly create demand in the land market, which stimulates a land price increase in the short term due to the competition effect $[58,61]$. Under the premise of limited land supply, the expansion of population scale not only stimulates the demand for production and residential land such as production land and storage land [38] but also promotes the production and circulation of consumer goods to a certain extent, which in turn promotes the rise of land prices for commercial services [54]. In addition, the concentration of capital and labor will form a "demographic dividend" and "intelligence enhancement effect" through the knowledge spillover effect $[55,60]$ to create conditions for industrial scale operation, while improving the allocation and production efficiency of factors and promoting urban industrial. This will indirectly affect the local land price level [46].

In summary, the four driving forces have their own pathways of action on land prices by promoting the free flow and optimal combination of factors, but they are also interlinked and synergistic (Figure 6). The degree of government monopoly over land and the degree of competition among real estate development companies in the land market will greatly affect the supply and demand in the land market [62]. Driven by a combination of administrative and market forces, the dual and multiplier effects of capital brought about by increased investment in fixed assets and real estate contribute directly to economic growth and industrial restructuring and upgrading, creating new jobs and income security for cities and creating attraction for mobile populations. The increase in the labor force improves the efficiency of labor in various sectors and promotes industrial agglomeration and scale upgrading, allowing capital elements to flow into the market through consumption and investment. This boosts economic growth and has a positive influence on the size of cities, leading to a significant increase in demand for urban land and investment in urban construction and pushing up land prices $[46,62]$. The cumulative effect of "increased investment-employment growth—higher incomes—influx of mobile population—industrial transformation and upgrading-economic development-rising land prices" [63] is a cycle that constitutes an important engine for increasing land prices of multiple industries in the region. In turn, the fair competition of the market recoups the rent-seeking costs and excess profits of developers back into the land price and the capital loss is used to finance the government's provision of public services and infrastructure construction, creating conditions for sustainable land financing and achieving sustainable operation of land finance, exerting the dominant effect of administrative power on land prices [51].

\subsection{Insights into Land Price Regulation for High-Quality Development}

To better promote the goal of integrated regional development, based on the spatiotemporal transmission and reciprocal feedback mechanism between land prices and factor flows that promote and constrain each other, targeted suggestions are made to regulate three types of land prices. The aim is to better utilize land prices as an information guide in the social economy and to promote integrated and coordinated regional development. First, the future government regulation of commercial service land prices should not simply use policies to compulsorily adjust them up or down but should pay close attention to demographic changes over a long period of time, play the interactive role of land and industry and form a positive interaction between industrial agglomeration and land prices. Second, since residential land prices are affected by the supply of residential land and the scale of property development in neighboring cities, real estate market regulation should focus on both "city linkage" and "city-specific policies". Third, for industrial land prices, with the improvement of land marketization, the effect of tax preferences on industrial land prices is weakening and local governments should gradually abandon the traditional "subsidized" way of attracting investment and instead promote the optimization and upgrading of industrial structure and build a soft and hard environment conducive to the "inflow" of labor to form a "magnetic" effect on external capital. In general, as the flow of 
resources and elements inside and outside the integrated region accelerates, the regulation and guidance of land prices of multiple industries should start from the perspective of factor flow and resource allocation and promote the active flow of factors within urban clusters by guiding the extension and diffusion of high-quality service resources from provincial capitals to other cities, narrowing the land price gap between municipalities directly under the central government, provincial capitals and cities in peripheral areas and thus improving the overall regional economic development efficiency and resource allocation capacity.

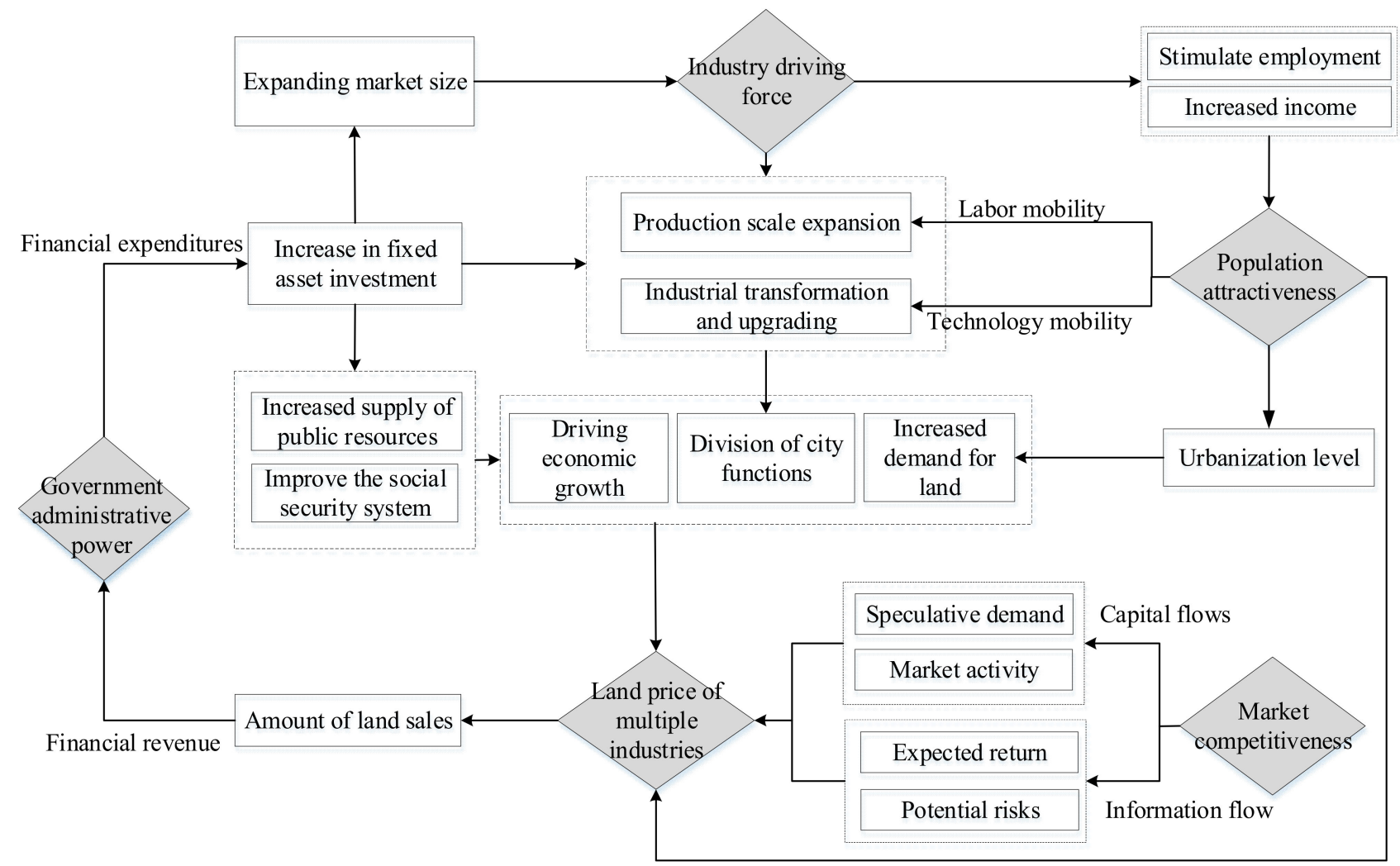

Figure 6. Mechanisms and feedback paths of spatio-temporal land price of multiple industries divergence in the Yangtze River Delta.

\section{Conclusions and Prospects}

\subsection{Conclusions}

Based on urban multiple industries land prices data from 2008 to 2018, the spatial autocorrelation and space time pattern mining method were used to analyze the spatial and temporal differentiation characteristics and evolution patterns of residential, commercial service and industrial land concession prices in the Yangtze River Delta integration region. Considering the spatial heterogeneity and non-stationarity of land prices, the influencing factors of residential land price divergence in Yangtze River Delta regions and counties were measured by spatial panel regression models to explore the intrinsic correlation and reciprocal feedbacks of spatial divergence of land prices in the integration region under the multiple influences of economy, population, policies and markets in the context of accelerated regional resource factor flow. The conclusions are as follows.

(1) The land price differences and spatial agglomeration of multiple industries are increasing in the Yangtze River Delta integration region. Vertically, because of the rapid urbanization process and the flow of resources and factors, the rural population continues to migrate to cities and the overall land price hierarchy continues to tilt toward larger cities. Horizontally, the center of gravity of urban development continues to tilt toward the east-central region, showing a multiple polar core land price distribution 
that jumps from municipalities directly under the central government and provincial capitals to the peripheral regions.

(2) From the perspective of spatial and temporal changes in land prices of multiple industries, residential land prices have grown the most rapidly due to rigid demand for housing and excessive speculation in the real estate market; commercial service and residential land prices are more fully influenced by market supply and demand mechanisms, showing the distribution characteristics of both spatial continuity and variability; industrial land has not formed a fully competitive market and the formation of prices depends mainly on cost promotion, with the smallest inter-year changes and growth.

(3) The factors influencing the temporal and spatial divergence patterns of residential and commercial service land prices are strongly similar. Since residential and commercial service land prices are mainly demand-oriented, land resources are more market-oriented and price formation is mainly determined by the supply and demand mechanism, which is more influenced by demographic and industrial factors, but industrial land is supply-oriented and price signals hardly reflect market supply and demand. The formation of land prices mainly depends on cost-driven factors and is more influenced by the city level, plot volume ratio and industrial structure.

(4) The formation of the spatial differentiation pattern of land prices in multiple industries is led by the government and is based on the population attraction and aggregation power generated by industrial development and coupled with the speculative and competitive nature of the market mechanism, which leads to redistribution among different cities of population, capital, technology, information and other factors and their reciprocal feedback, thus promoting the division of urban functions and regional economic development, ultimately acting on the process of land price.

\subsection{Prospects}

On a national scale, the Yangtze River Delta represents a more advanced stage of regional integrated development and its urban land price growth and spatial divergence patterns reflect, to a certain extent, the general patterns and development trends of the spatial and temporal evolution of house prices in other urban agglomerations. With this in mind, this paper undertakes two areas of work. Firstly, based on a longer time series and smaller spatial scale of urban land price data, we can understand the growth pattern and spatial differentiation characteristics of each of the three types of land prices in the Yangtze River Delta. Secondly, through the analysis of the SDM, the demographic and industrial factors are the main factors influencing the three types of land prices and this conclusion has been confirmed by existing studies [64,65]. However, most previous studies on land prices have overemphasized the impact of economic and policy factors on land prices [52], with an insufficient understanding of the importance of the impact of population and industrial factors on land prices [11,53]. This paper argues that the macro-level land rent formed by the different degrees of exchange and aggregation of economic resource factors among different cities is an important reason for the spatial differentiation of land prices. The change in land price and the change in industrial structure is an adaptive adjustment process. The adjustment and upgrading of industrial structures bring about the growth or transfer of economic factors, which changes the function of cities and thus reshapes the land use structure, resulting in the differential distribution of land prices among different cities. Industrial, market and administrative forces are all mediated by the population factor to affect land demand and thus land prices, so population and industrial factors have a greater impact on the land prices of multiple industries. The spatial differentiation of land prices in multiple industries is a physical expression of regional differences in resource agglomeration capacity and allocation ability under the leadership of national macro policies, which can achieve the regulation of regional high-quality development by influencing regional factor flows [41]. Curbing excessive land price rises and excessive divergence is both a necessary means to effectively promote the healthy development of 
the land market and a proper means to narrow the differences in regional economic and social development and promote higher quality integrated development in the Yangtze River Delta region.

It should still be pointed out that in this paper, in terms of interpreting the mechanisms and reasons behind the changes in land prices of multiple industries, the impact coefficients may have the disadvantage of inaccurate estimation of being too high or too low because the data obtained for the indicators were only available for three years, 2008, 2013 and 2018 and not for 10 consecutive years; some relevant important factors were not included in the spatial panel model due to insignificant statistical tests and only the urban commercial service land price, residential land price and industrial land price were considered to have common influencing factors. However, the spatial variation of land price in regional cities is characterized by diversity and complexity and there are differences in the intensity of specific factors in different locations and types of land use, which makes it more difficult to analyze the causes of regional urban land price differences and is also the focus of future research. In the future, multi-source geographic big data can be used to simulate urban land price distribution to remedy the problems of a subjective way of quantifying elements, the rigid model form and low prediction accuracy in traditional land price research based on empirical statistical methods and try to use integrated learning methods to simulate the nonlinear interaction between land price and its potential influencing factors, so as to provide a reference for realizing refined land use management and smart city construction. As far as the land market is concerned, with the development of polycentric cities and regional economies, the inter-regional linkages have become closer and it is necessary not only to pay attention to the trend of land price, but also to systematically analyze the macro, meso and micro factors that affect land price.

Author Contributions: Conceptualization, D.G.; methodology, S.H.; software, G.H.; validation, S.H., J.S. and M.L.; formal analysis, S.H. and D.G.; investigation, S.H. and J.S.; resources, Y.L.; data processing, Y.M., M.L. and G.H.; writing—original draft preparation, S.H.; writing—review and editing, G.H.; visualization, S.H. and G.H.; supervision, D.G. and J.S.; project administration, D.G. and M.L.; funding acquisition, D.G., Y.L. and M.L. All authors have read and agreed to the published version of the manuscript.

Funding: This research was funded by "the National Natural Science Foundation of China" (grant number 41901204, 42171171, 42001125), "The Foundation of Humanity and Social Sciences of the Ministry of Education of China" (grant number 19YJCZH036, 20YJC790093), "China Postdoctoral Science Foundation" (grant number 2019M660109, 2021T140303), “Jiangsu Provincial Science Foundation" (grant number BK20190717) and "Jiangsu Provincial Social Science Foundation" (grant number 19GLC002), "Natural Science Foundation of the Jiangsu Higher Education Institutions" (grant number 19KJB170018).

Institutional Review Board Statement: Not applicable.

Informed Consent Statement: Not applicable.

Data Availability Statement: Not applicable.

Conflicts of Interest: The authors declare no conflict of interest.

\section{References}

1. Yang, X. China's rapid urbanization. Science 2013, 342, 310-311. [CrossRef] [PubMed]

2. Li, H.; Wei, Y.H.D.; Yu, Z.; Tian, G. Amenity, accessibility and housing values in metropolitan USA: A study of Salt Lake County, Utah. Cities 2016, 59, 113-125. [CrossRef]

3. Ge, D.; Lu, Y. A strategy of the rural governance for territorial spatial planning in China. J. Geogr. Sci. 2021, 31, 1349-1364. [CrossRef]

4. Du, J.; Thill, J.C.; Peiser, R.B. Land pricing and its impact on land use efficiency in post-land-reform China: A case study of Beijing. Cities 2016, 50, 68-74. [CrossRef]

5. Bai, X.; Shi, P.; Liu, Y. Society: Realizing China's urban dream. Nature 2014, 509, 158-160. [CrossRef] [PubMed]

6. Hu, S.; Yang, S.; Li, W.; Zhang, C.; Xu, F. Spatially non-stationary relationships between urban residential land price and impact factors in Wuhan city, China. Appl. Geogr. 2016, 68, 48-56. [CrossRef] 
7. Su, S.; Zhang, J.; He, S.; Zhang, H.; Hu, L.; Kang, M. Unraveling the impact of TOD on housing rental prices and implications on spatial planning: A comparative analysis of five Chinese megacities. Habitat Int. 2021, 107, 102309. [CrossRef]

8. An, P.; Li, C.; Duan, Y.; Ge, J.; Feng, X. Inter-metropolitan land price characteristics and pattern in the Beijing-Tianjin-Hebei urban agglomeration, China. PLoS ONE 2021, 16, 0256710. [CrossRef]

9. Hu, S.; Cheng, Q.; Wang, L.; Xie, S. Multifractal characterization of urban residential land price in space and time. Appl. Geogr. 2012, 34, 161-170. [CrossRef]

10. Yang, Z.; Li, C.; Fang, Y. Driving factors of the industrial land transfer price based on a geographically weighted regression model: Evidence from a rural land system reform pilot in China. Land 2020, 9, 7. [CrossRef]

11. Nasr, K.; Boris, A.P. Economic, demographic and environmental factors affecting urban land prices in the Arab sector in Israel. Land Use Pol. 2016, 50, 518-527.

12. Braimoh, A.K.; Onishi, T. Spatial deteminants of urban land use change in Lagos. Nigeria. Land Use Pol. 2007, $24,502-515$. [CrossRef]

13. $\mathrm{Hu}, \mathrm{S}$.; Cheng, Q.; Wang, L.; Xu, D. Modeling land price distribution using multifractal IDW interpolation and fractal filtering method. Landsc. Urban Plan. 2013, 110, 25-35. [CrossRef]

14. Yang, L.; Zhou, J.; Shyr, O.F.; Huo, D. Does bus accessibility affect property prices? Cities 2019, 84, 56-65. [CrossRef]

15. Yang, S.; Hu, S.; Wang, S.; Zou, L. Effects of rapid urban land expansion on the spatial direction of residential land prices: Evidence from Wuhan, China. Habitat Int. 2020, 101, 102186. [CrossRef]

16. Wu, Y.; Zhang, X.; Skitmore, M.; Song, Y.; Hui, E.C.M. Industrial land price and its impact on urban growth: A Chinese case study. Land Use Pol. 2014, 36, 199-209. [CrossRef]

17. He, Q.; Zhou, J.; Tan, S.; Song, Y.; Zhang, L.; Mou, Y.; Wu, J. What is the developmental level of outlying expansion patches? A study of 275 Chinese cities using geographical big data. Cities 2020, 105, 102395. [CrossRef]

18. Xu, X.; Jin, X.; Zhang, Z.; Han, J.; Sun, W.; Xiang, X.; Xie, J.; Zhou, Y. Evaluation of health status in national housing market at the county level. Geogr. Res. 2017, 36, 85-96.

19. Song, J.; Jin, X.; Tang, J.; Zhang, Z.; Ding, N.; Zhao, J.; Zhou, Y. Analysis of influencing factors for urban land price and its changing trend in China in recent years. Acta Geogr. Sin. 2011, 66, 1045-1054.

20. Ding, C.; Zhao, X. Land market, land development and urban spatial structure in Beijing. Land Use Pol. 2014, 40, 83-90. [CrossRef]

21. Garang, Z.; Wu, C.; Li, G.; Zhuo, Y.; Xu, Z. Spatio-temporal non-stationarity and its influencing factors of commercial land price: A case study of Hangzhou, China. Land 2021, 10, 317. [CrossRef]

22. Cheng, J. Analysis of commercial land leasing of the district governments of Beijing in China. Land Use Pol. 2021, 100, 104881. [CrossRef]

23. Dongkwan, L.; Choongik, C. An Analysis of the Effects of Development-Restricted Areas on Land Price Using Spatial Analysis. Land 2021, 10, 660. [CrossRef]

24. Meenakshi, S. Harnessing land value capture: Perspectives from India's urban rail corridors. Land Use Pol. 2021, 108, 105526. [CrossRef]

25. Lord, A. Making space: Property development and urban planning. Prog. Hum. Geogr. 2006, 30, 836-838. [CrossRef]

26. Spencer, G.M. Knowledge neighbourhoods: Urban form and evolutionary economic geography. Reg. Stud 2015, 49, 883-898. [CrossRef]

27. Gao, L.; Jiang, F. Higher Quality Integration in the Yangtze River Delta: Stage Features, Dilemmas, and Action Frameworks Gao Lina, Jiang Fuxin. Economist 2020, 3, 66-74.

28. Babenko, V.O. Modeling of factors influencing innovation activities of agricultural enterprises of Ukraine. Sci. Bull. Polissia 2017, 1, 115-121. [CrossRef]

29. Gao, H. Public land leasing, public productive spending and economic growth in Chinese cities. Land Use Pol. 2019, 88, 104076. [CrossRef]

30. Lucas, R.E. Why doesn't capital flow from rich to poor countries? Am. Econ. Rev. 1990, 80, 92-96.

31. Martin, R.; Sunley, P. Towards a developmental turn in evolutionary economic geography? Reg. Stud. 2015, 49, 712-732. [CrossRef]

32. Ge, D.; Long, H.; Zhang, Y.; Ma, L.; Li, T. Farmland transition and its influences on grain production in China. Land Use Pol. 2018, 70, 94-105. [CrossRef]

33. Lu, X.; Jiang, X.; Gong, M. How land transfer marketization influence on green total factor productivity from the approach of industrial structure? Evidence from China. Land Use Pol. 2020, 95, 104610. [CrossRef]

34. Niu, B.; Ge, D.; Yan, R.; Ma, Y.; Sun, D.; Lu, M.; Lu, Y. The evolution of the interactive relationship between urbanization and land-use transition: A case study of the Yangtze River Delta. Land 2021, 10, 804. [CrossRef]

35. Nehrey, M.; Kaminskyi, A.; Komar, M. Agro-economic models: A review and directions for research. Period. Eng. Nat. Sci. 2019, 7, 702-711. [CrossRef]

36. Chen, J.; Wu, F. Housing and land financialization under the state ownership of land in China. Land Use Pol. 2022, 112, 104844. [CrossRef]

37. Andy, L.K.; Bitter, C. Spatial econometrics, land values and sustainability: Trends in real estate valuation research. Cities 2012, $29,19-25$.

38. Song, W.; Liu, C. The price differentiation mechanism of commercial housing in the Yangtze River Delta. Geogr. Res. 2018, $37,92-102$ 
39. Zhang, Z.; Wu, D.; Zhou, S. Production factor mobility, regional coordination and integration and economic growth. Landsc. Urban Plan. 2018, 37, 58-66.

40. Chauvin, J.P.; Glaeser, E.; Ma, Y.; Tobio, K. What is different about urbanization in rich and poor countries? Cities in Brazil, China, India and the United States. J. Urban Econ. 2017, 98, 17-49. [CrossRef]

41. Song, W.; Chen, Y.; Sun, J.; He, M. Spatial differentiation of urban housing prices in integrated region of Yangtze River Delta. Acta Geogr. Sin. 2020, 75, 2109-2125.

42. Ge, D.; Long, H.; Qiao, W.; Wang, Z.; Sun, D.; Yang, R. Effects of rural-urban migration on agricultural transformation: A case of Yucheng City, China. J. Rural Stud. 2020, 76, 85-95. [CrossRef]

43. Yin, S.; Li, Z.; Song, W.; Ma, Z. Spatial Differentiation and Influence Factors of Residential Rent in Nanjing Based on Geographical Detector. J. Geo-Inf. Sci. 2018, 20, 1139-1149.

44. Cheng, Y.; Wang, Z.; Zhang, S.; Ye, X.; Jiang, H. Spatial econometric analysis of carbon emission intensity and its driving factors from energy consumption in China. Acta Geogr. Sin. 2013, 68, 1418-1431.

45. Chai, Z.; Zhao, S.; Tang, Q. Divergence of Urban Function and Its Influences on Urban Land Prices: Evidence from Cities in the Yangtze River Economic Belt in China. J. Urban Plan. Dev 2021, 147, 04021039. [CrossRef]

46. Jing, C. Analyzing the factors influencing the choice of the government on leasing different types of land uses: Evidence from Shanghai of China. Land Use Pol. 2020, 90, 104303. [CrossRef]

47. Han, W.; Zhang, Y.; Cai, J.; Ma, E. Does Urban Industrial Agglomeration Lead to the Improvement of Land Use Efficiency in China? An Empirical Study from a Spatial Perspective. Sustainability 2019, 11, 986. [CrossRef]

48. Li, H.; Chen, K.; Yan, L.; Zhu, Y.; Liao, L.; Chen, Y. Urban Land Use Transitions and the Economic Spatial Spillovers of Central Cities in China's Urban Agglomerations. Land 2021, 10, 644. [CrossRef]

49. Yuan, F.; Wei, Y.D.; Xiao, W. Land marketization, fiscal decentralization, and the dynamics of urban land prices in transitional China. Land Use Pol. 2019, 89, 104208. [CrossRef]

50. Su, F.; Tao, R. The China model withering? Institutional roots of China's local developmentalism. Urban Stud. 2017, 54, 230-250. [CrossRef]

51. Han, W.; Zhang, X.; Zheng, X. Land use regulation and urban land value: Evidence from China. Land Use Pol. $2020,92,104432$. [CrossRef]

52. Zhong, T.; Zhang, X.; Huang, X.; Liu, F. Blessing or curse? Impact of land finance on rural public infrastructure development. Land Use Pol. 2019, 85, 130-141. [CrossRef]

53. Zhang, X.; Lin, Y.; Wu, Y.; Skitmore, M. Industrial land price between China's Pearl River Delta and Southeast Asian regions: Competition or Coopetition? Land Use Pol. 2017, 61, 575-586. [CrossRef]

54. Kang, J.; Xu, w.; Yu, l.; Ning, Y. Localization, urbanization and globalization: Dynamic manufacturing specialization in the YRD mega-city conglomeration. Cities 2020, 99, 102641. [CrossRef]

55. Zhang, W.; Derudder, B.; Wang, J.; Shen, W. Regionalisation in the Yangtze River Delta, China, from the perspective of intercity daily mobility. Reg. Stud. 2018, 52, 528-541. [CrossRef]

56. Chen, K.; Wang, L.; Tu, S.; Long, H. Efficiency and coordination: How does land market promote the development of urbanization. Econ. Geogr. 2019, 39, 37-47.

57. Yuan, D.; Yau, Y.; Hou, H.; Liu, Y. Factors influencing the project duration of urban village redevelopment in contemporary China. Land 2021, 10, 707. [CrossRef]

58. Li, X.; Hui, E.C.M.; Shen, J. The consequences of Chinese outward real estate investment: Evidence from Hong Kong land market. Habitat Int. 2020, 98, 102151. [CrossRef]

59. Hui, E.C.; Leung, B.Y.; Yu, K. The impact of different land-supplying channels on the supply of housing. Land Use Pol. 2014, 39, 244-253. [CrossRef]

60. Marcos, Á.; Béatrice, D.; Lewis, D.; Claudia, G.; Nicola, P. Unveiling the local determinants of population growth in the European Union. Growth Chang. 2021, 52, 150-166.

61. Fan, J.; Zhou, L.; Yu, X.; Zhang, Y. Impact of land quota and land supply structure on China's housing prices: Quasi-natural experiment based on land quota policy adjustment. Land Use Pol. 2021, 106, 105452. [CrossRef]

62. Yuan, F.; Wei, Y.D.; Wu, J. Amenity effects of urban facilities on housing prices in China: Accessibility, scarcity, and urban spaces Cities 2020, 96, 102433. [CrossRef]

63. Jiang, G.; Ma, W.; Qu, Y. How does sprawl differ across urban built-up land types in China? A spatial-temporal analysis of the Beijing metropolitan area using granted land parcel data. Cities 2016, 58, 1-9. [CrossRef]

64. Quigley, J.M. Local Land-use Controls and Demographic Outcomes in a Booming Economy. Urban Stud. 2004, 41, 389-421. [CrossRef]

65. Yuan, Y.; Liu, Y.; Li, Y.; Li, J. Measure of urban-rural transformation in Beijing-Tianjin-Hebei region in the new millennium: Population-land-industry perspective. Land Use Pol. 2018, 79, 595-608. 